\title{
Theoretical and methodological bases of organization of cooperative education in higher educational institutions
}

\author{
Zelenska L., Zelenskyi B. ${ }^{*}$ \\ Kharkiv National Pedagogical University named after G. S. Skovoroda, Kharkiv, Ukraine
}

Received: 20.03.2019 Accepted: 10.04 .2019

\begin{abstract}
The article proves the expediency of extensive introduction of co-operative learning technology in the educational process in Ukrainian higher educational institutions. The purpose of the research is to reveal theoretical foundations of the co-operative learning technology and to describe the methodical tools of its implementation in the practice of higher educational institutions in Ukraine. In order to achieve the goal a set of research methods is defined: general scientific (source study analysis, descriptive analytical method, comparison, opposition, classification, systematization) and special (historical genesis, comparison) techniques. The use of given methods has permitted to determine the essence of the technology of cooperative learning (structured learning activitiy of small groups where members are working together (co-operating) to achieve the maximum effectiveness of the learning process); its (the essence's) features (positive interaction, direct support, social competence, own assessment, personal responsibility), teacher functions in terms of the co-operative learning organization (facilitator, assistant, equal member of the group), to uncover the theoretical foundations of the technology of cooperative learning (the theory of social interdependence, the development of cognition (intelligence), the ideas of behaviorism), to describe the basic methods and techniques of organization of cooperative learning (S. Kagan), to give examples and to formulate methodological recommendations for the implementation of the technology of cooperative teaching in the practice of higher education institutions of Ukraine (STAD methods, "Jigso", training in achievement teams, training tournament, team support of individual training, cooperative mutual learning, group research, "Ko-op Ko-op ", searching method, "Studying together", three-tiered interviewing, numbering of students, method of discussion by L. Mitin, method of problematic seminar lesson). The emphasis is placed on the fact that the use of these methods has powerful levers for the development of student's motivation for learning, critical thinking skills, cooperation, cocreation, collective action, ability to solve complex problems basing on the analysis of circumstances and relevant information, to approach in a balanced manner to evaluation of alternative ideas and to discuss.
\end{abstract}

Key words: technology, cooperative education, institutions of higher education, Ukraine, methods, techniques.

\section{Теоретичні і методичні засади організації кооперативного навчання у закладах вищої освіти}

\author{
Зеленська Л. Д., Зеленський Б. Р. \\ Харківський національний педагогічний університет імені Г. С. Сковороди, Харків, Україна
}

\begin{abstract}
Анотація. У статті доведено доцільність широкого впровадження технології кооперативного навчання в освітній процес закладів вищої освіти України. Сфрормульовано мету дослідження, що полягає у розкритті теоретичних засад технології кооперативного навчання й характеристиці методичного інструментарію ї̈ реалізації в практиці роботи закладів вищої освіти України. Для досягнення мети визначено комплекс методів дослідження: загальнонаукові (джерелознавчий аналіз, описово-аналітичний метод, порівняння, зіставлення, класифікація, систематизація) та спеціальні (історико-генезисний, компаративістський). Застосування названих методів дозволило визначити суть технології кооперативного навчання (структурована навчальна діяльність малих груп, члени яких працюють разом (кооперуються) задля досягнення максимальної ефрективності процесу навчання), ії ознаки (позитивна взаємодія, безпосередня підтримка, соціальна компетентність, власна оцінка, персональна відповідальність), функції викладача в умовах організації
\end{abstract}

\footnotetext{
Corresponding Author: Zelenskyi Bohdan Romanovych. Tel. +38 0507868765. E-mail: zelja18061993@gmail.com Higher School H.S. Skovoroda Kharkiv National Pedagogical University 29 Alchevskyh Street, Kharkiv, Ukraine, 61002.

Biдповідальний автор: Зеленський Богдан Романович. Тел. +38 0507868765. E-mail: zelja18061993@gmail.com Харківський національний педагогічний університет імені Г.С. Сковороди, вул. Алчевських, 29, м. Харків, Україна, 61002.
} 
кооперативного навчання (фасилітатор, помічник, рівноправний учасник групи). Розкрити теоретичні основи технології кооперативного навчання (теорія про соціальну взаємозалежність, про розвиток пізнання (інтелекту), ідеї біхевіоризму). Охарактеризувати базові методи й прийоми організації кооперативного навчання (С. Каган), навести приклади й сформулювати методичні рекомендації щодо реалізації технології кооперативного навчання в практиці роботи закладів вищої освіти України (методи СТАД, «Джигсо», навчання в командах досягнень, навчального турніру, командної підтримки індивідуального навчання, кооперативного взаємонавчання, групового дослідження, «Ко-оп Ко-оп», пошуковий метод, «Навчаємося разом», триступеневе інтерв'ювання, нумерація студентів, метод дискусії Л. Мітіної, метод проблемного семінарського заняття). Акцентовано увагу на тому, що використання цих методів має потужні важелі для розвитку мотивації студентської молоді до навчання, формування навичок критичного мислення, співпраці, співтворчості, колективної дії, умінь розв'язувати складні проблеми на основі аналізу обставин і відповідної інформації, виважено підходити до оцінювання альтернативних думок і вести дискусію.

Ключові слова: технологія, кооперативне навчання, заклади вищої освіти, Україна, методи, прийоми.

\title{
Теоретические и методические основы организации кооперативного обучения в учреждениях высшего образования
}

\author{
Зеленская Л. Д., Зеленский Б. Р. \\ Харьковский национальный педагогический университет имени Г. С. Сковороды, Харьков, Украина
}

\begin{abstract}
Аннотация. В статье доказана целесообразность широкого внедрения технологии кооперативного обучения в образовательный процесс высших учебных заведений Украины. Сформулирована цель исследования, которая заключается в раскрытии теоретических основ технологии кооперативного обучения и характеристике методического инструментария ее реализации в практике работы высших учебных заведений Украины. Для достижения цели определен комплекс методов исследования: общенаучные (источниковедческий анализ, описательно-аналитический метод, методы сравнения, сопоставления, классификации, систематизации) и специальные (историко-ґенезисный, компаративистский). Применение названных методов позволило определить суть технологии кооперативного обучения (структурированная учебная деятельность малых групп, члены которых работают вместе (кооперируются) для достижения максимальной эффективности процесса обучения), ее признаки (позитивное взаимодействие, непосредственная поддержка, социальная компетентность, собственная оценка, персональная ответственность), функции преподавателя в условиях организации кооперативного обучения (фасилитатор, помощник, равноправный участник группы). Раскрыть теоретические основы технологии кооперативного обучения (теория о социальной взаимозависимости, о развитии познания (интеллекта), идеи бихевиоризма). Представить характеристику базовых методов и приемов организации кооперативного обучения (С. Каган), привести примеры и сформулировать методические рекомендации по реализации технологии кооперативного обучения в практике работы высших учебных заведений Украины (методы СТАД, «Джигсо», обучение в командах достижений, учебный турнир, командная поддержка индивидуального обучения, кооперативное взаимообучение, групповое исследование, «Ко-оп Ко-оп», поисковый метод, «Учимся вместе», трехступенчатое интервьюирование, нумерация студентов, метод дискуссии Л. Митиной, метод проблемного семинарского занятия). Акцентировано внимание на том, что использование этих методов имеет мощные рычаги для развития мотивации студенческой молодежи к обучению, формирования навыков критического мышления, сотрудничества, сотворчества, коллективного действия, умений решать сложные проблемы на основе анализа обстоятельств и соответствующей информации, взвешенно подходить к оценке альтернативных мнений и вести дискуссию
\end{abstract}

Ключевые слова: технология, кооперативное обучение, высшие учебные заведения, Украина, методы, приемы.

\section{Bcmyn}

Одним із ключових завдань ЗВО України є підготовка конкурентоспроможних фахівців, які не тільки на професійному рівні володіють основами спеціальності, але й здатні виражати особистісну соціальну позицію, власне ставлення до матеріалу, що вивчається, висувати нові ідеї, пропозиції, проекти. Такий підхід вимагає перегляду знаннєвої парадигми у вищій школі, широке впровадження інтерактивних методів і технологій навчання, які слугують підвалинами формування в майбутніх фахівців навичок критичного мислення, співпраці, співтворчості, колективної дії, умінь розв'язувати складні проблеми на основі аналізу обставин і відповідної інформації, виважено підходити до оцінювання альтернативних думок і вести дискусію. За таких умов студент перетворюється із об'єкта впливу на суб'єкта взаємодії, що значно підвищує його умотивованість і активність у процесі навчання. 
Однією з таких технологій є технологія кооперативного навчання, в основі якої лежить структурована навчальна діяльність малих груп, члени яких працюють разом (кооперуються) задля досягнення максимальної ефективності процесу навчання. Теоретичні засади кооперативного навчання знайшли висвітлення в працях Л. Виготського [15], Дж. Дьюи [18], С. Кагана [7; 8], Ж. Піаже [21] та ін. Однак сама технологія організації кооперативного навчання детально розроблялася трьома групами американських учених із університету Джона Хопкінса (Р. Славін) [12], університету Міннесота (Р. Джонсон і Д. Джонсон) [5; 6] та Каліфорнійського університету (Е. Аронсон) [2]. На сьогодні у світовій педагогічній думці існує спеціальний напрям досліджень (collaborative learning), пов'язаний 3 організацією навчання осіб різного віку у складі малих груп (Е.Аронсон [1], [3], Е. Холубек [4], Дж. МакГрегор [10], С. Ренегар [11], М. Вейднер [13] та ін.).

На вітчизняному освітньому просторі визначена проблема знайшла часткове обґрунтування в працях Н. Волкової [14], Н. Гагіної [16], О. Комар [19], Л. Пироженко [23], О. Пометун [22; 23], Г. Селевка [25], В. Стрельнікова [26] та ін. переважно у розрізі інтерпретації інтерактивних методів навчання.

Mema роботи: розкрити теоретичні засади технології кооперативного навчання й охарактеризувати методичний інструментарій реалізації названої технології в практиці роботи закладів вищої освіти України.

\section{II Матеріали і методи дослідження}

Для досягнення мети роботи використано комплекс методів дослідження:

- загальнонаукові (джерелознавчий аналіз, описово-аналітичний метод, порівняння, зіставлення, класифікація, систематизація), що забезпечили пошук, обробку й інтерпретацію масиву автентичної літератури, історико-педагогічних та психолого-педагогічних джерел 3 проблеми дослідження, обгрунтування теоретичних засад кооперативного навчання, визначення його особливостей і умов ефективності, характеристику різновидів кооперативного навчання і методик їх організації в практиці роботи закладів вищої освіти;

- спеціальні: історико-генезисний - дав змогу розкрити еволюцію досліджуваного феномену в часі і просторі; компаративістський - склав основу для порівняння й зіставлення методичного інструментарію організації кооперативного навчання у вітчизняній і зарубіжній вищих школах.

\section{III Результати}

У вітчизняному науковому просторі серед дослідників [14; 16; 22; 26] не існує єдиного підходу до тлумачення поняття «кооперативне навчання». Названу дефрініцію трактують як вид навчання, метод навчання, технологію навчання. Ми схильні розглядати кооперативне навчання як дидактичну технологію, що дозволяє досягти за допомогою інтенсифрікації навчального процесу змін у його процесуальному й результативному аспектах. У процесі реалізації в умовах вищої професійної освіти названа технологія набуває педагогічного змісту, поєднуючи в собі методи, прийоми, засоби навчання, а також різні форми суб'єкт-суб'єктної взаємодії, які в комплексі створюють широкі можливості для формування у студентів самостійності, критичного мислення, оволодіння навичками пізнавальної діяльності і соціальними вміннями.

Зважаючи на це, серед основних ознак кооперативної технології навчання,виділяють такі:

- позитивний взаємозв'язок: успіх кожного студента залежить від добропорядності інших членів групи. Студенти у такий спосіб навчаються взаємній відповідальності і роботі в команді;

- безпосередня підтримка: студенти обмінюються думками, джерелами і матеріалами, оцінюють виконання роботи кожним членом команди з метою отримання загального результату;

- персональна відповідальність: кожен студент несе відповідальність за результати групової діяльності й за свою частку роботи, оскільки успіх команди залежить від індивідуальної роботи кожного ії члена;

- соціальна компетентність: студенти навчаються взаємній довірі і повазі один до одного, у них формуються уміння й навички керувати діями інших (лідерство), ухвалювати рішення, спілкуватися та долати конфоікти; 
- власна оцінка: студенти вчаться оцінювати свій внесок в успіх групової роботи, а також оцінювати спільну роботу групи з позиції доцільності обраних методів і виокремлювати причини невдач.

За такої організації освітнього процесу суттєвих змін зазнають функції викладача. Він виступає як фасилітатор, помічник, рівноправний учасник групи, що забезпечує формування в студентів необхідних для співпраці умінь, як-от: координувати свою діяльність з діяльністю партнерів; ставати на позицію інших і змінювати свою; надавати своїм партнерам допомогу і користуватися їхньою допомогою; рефлексувати свої дії і дії інших членів групи; з повагою ставитися до думки кожного; надавати більш високі пріоритети досягненню колективної мети; не допускати переростання розбіжностей в зіткнення позицій та інтересів; запобігати виникненню конфліктів. Його головне завдання полягає в тому, щоб уселити віру в можливість успішного досягнення мети і спонукати студентів до самостійного пошуку.

Підкреслимо, що спроби широкого впровадження кооперативного навчання у практику вищої школи України припадають на кінець 20-х - початок 30-х років XX століття, коли набув поширення бригадно-лабораторний метод навчання. Студентська група поділялася на бригади за різними принципами:

- змішані (в кожну бригаду призначали студентів-відмінників і тих, хто відставав у навчанні);

- за рівнем успішності (у першу бригаду - «відмінників», у другу - «хорошистів», у третю «трієчників);

- за місцем проживання.

Кожна бригада навчалася за індивідуальним планом, який містив рекомендації щодо виконання роботи, перелік навчальної літератури, зразки виконання практичних завдань і вправ, а також контрольні запитання. Про результати роботи звітував бригадир, а оцінка виставлялася всім членам бригади на основі поданого звіту. Заліки також складали бригадою, що виключало індивідуальний облік успішності студентів, породжувало безсистемність у набутті знань і нівелювало персоніфікований підхід. Постановою ЦКВКП(б) від 25 серпня 1932 р. цей метод було засуджено.

Утім зарубіжна педагогічна думка (Д. Джонсон, Р. Джонсон, Е. Джонсон-Холубек) й освітня практика довели ефективність кооперації у навчанні. Теоретичні основи кооперативного навчання сфрормувалися під впливом уявлень про соціальну взаємозалежність, про розвиток пізнання (інтелекту) та ідей біхевіоризму. Пояснення суті соціальної взаємодії належить К. Коффці - одному із засновників гештальтпсихології, ідеї якої набули подальшого розвитку в 20-30-ті роки XX століття у працях К. Левіна. Ученому, зокрема, належить уведення положень, згідно з якими основою будь-якої групи $\epsilon$ взаємозалежність між її членами, що створюється завдяки спільній меті, і завдяки якій група виступає динамічним цілим: зміна становища одного члена групи зумовлює зміну становища будь-якого іншого члена цієї ж групи. Джерелом руху групи до спільної мети є наявна в ній напруга [9].

Д. Джонсон і Р. Джонсон обґрунтували теорію соціальної взаємозалежності, згідно з якою дії індивідів, а отже, і результати діяльності групи, визначаються характером наявної між ними взаємозалежності. Так, позитивна взаємозалежність (співробітництво) виступає передумовою того, що члени групи, прагнучи досягти спільних цілей, стимулюють і підтримують один одного, тоді як негативна взаємозалежність (конкуренція, змагання) зазвичай призводять до конфрронтації. Якщо ж взаємозалежність відсутня, немає і взаємодії - кожний працює окремо. Розкриваючи суть групової навчальної діяльності, дослідники вказували на те, що кожна група виконує завдання і працює над ним доти, доки всі члени групи повністю не усвідомлять і не виконають свою частку роботи. При цьому спільні зусилля спрямовані на досягнення спільної мети, успіх кожного поділяють його товариші, всіх членів групи очікує «спільна участь».

Щодо впливу кооперації (співробітництва) на розвиток пізнання особистості, то на його користь у науковій літературі наводилися такі аргументи: між людьми, які займаються спільною роботою, обов'язково виникають дискусії, у процесі яких народжуються і розв'язуються «інтелектуальні (пізнавальні) конфрлікти», а також переглядаються і коригуються помилкові судження; знання за своєю природою соціальне, воно є результатом колективних зусиль, спрямованих на усвідомлення, вивчення і вирішення конкретних проблем.

Водночас, біхевіористська теорія обстоювала думку про те, що спільні дії, які одержують схвалення, будуть повторюватися. Тому важливе значення має «зовнішній чинник» - об'єктивна оцінка 
результатів, досягнутих тими, хто навчається в групі. Кооперативне навчання передбачає надання членам групи стимулів для участі в роботі групи.

Названі теорії вказують на суттєві переваги кооперативного навчання у порівнянні 3 індивідуальним, а також тим, що грунтується на конкуренції. Утім, між цими теоріями існують і суттєві розбіжності. Так, теорія соціальної взаємозалежності вказує на те, що спільні зусилля базуються на внутрішній мотивації, яка породжується внутрішньо особистісними фракторами і загальним прагненням досягти поставлених цілей. Натомість біхевіористська теорія навчання наголошує на тому, що кооперативні зусилля збільшуються завдяки зовнішній мотивації отримати винагороду. Теорія соціальної взаємозалежності фокусується на концепціях відносин, які досліджують, що відбувається між окремими особистостями, у той час як когнітивно-розвивальна концепція бере до уваги зміни окремої особистості (наприклад, дисбаланс, інтелектуальні зміни тощо) [17].

Зазначене вище дозволяє аргументовано стверджувати, що кооперація у процесі навчання буде ефективною лише за певних умов. Елементарний розподіл студентів на групи і визначення обсягу групових завдань не гарантує справжньої кооперації. Для цього, по-перше, викладач має постійно дбати про те, щоб кожен студент розумів, що він тісно пов'язаний з іншими, і не може досягти успіху, поки інші не виконають роботу. Позитивний взаємозв'язок удається підтримувати, наприклад, сумуючи загальні оцінки (якщо 90\% всіх членів групи відповіли на тест правильно, кожен отримує п'ять заохочувальних балів), розподіляючи матеріал (надавати кожному члену групи частку загальної інформації і вимагати доповнити їі інформацією, підготовленою іншими), запроваджуючи додаткові ролі (доповідач, рецензент, опонент, читач тощо). По-друге, стимулювати індивідуальну відповідальність студентів шляхом: а) індивідуального тестування; б) запровадження пояснень кожним студентом одному із членів групи вивченого матеріалу; в) спостереження за групою й фріксації внеску кожного її члена. Студенти вивчають разом те, що згодом зможуть використати індивідуально. По-третє, забезпечувати стимулювання студентами успішності один одного. Організований у такий спосіб когнітивний процес набуває рис вербально пояснювального навчання. Студенти набувають особистісного досвіду щодо того, як розв'язувати проблеми, як навчати своїх однокурсників, як пов'язувати новий матеріал із набутими раніше знаннями. Це зумовлює вияв внутрішньо особистісних стосунків, забезпечує зворотний зв'язок, допомагає учасникам групи краще пізнати один одного на особистісному й професійному рівнях. По-четверте, постійно дбати про формування в студентів навичок соціальної поведінки. Лідерству, умінню приймати рішення, комунікувати, управляти конфліктами, як і академічним навичкам, слід навчати цілеспрямовано й систематично. Співробітництво студентів, котрі не мають відповідних навичок соціальної поведінки,приречене на невдачу. Зазначимо, що процедури і стратегії навчання таким навичкам детально описані у працях зарубіжних учених $[1 ; 3 ; 5 ; 6 ; 13]$. По-п'яте, спрямовувати студентів на пошук способів удосконалення групової роботи. Серед таких способів найбільш ефективними є: а) визначення кроків, які виявилися найбільш дієвими у забезпеченні успішної взаємодії й досягненні кожним членом групи поставленої цілі; б) ухвалення рішень щодо того, які моделі поведінки варто розвивати, а які змінювати [17].

Вище зазначене дозволяє аргументовано стверджувати, що успішність реалізації названої технології прямо пропорційно залежить не лише від підготовленості студентів до групової взаємодії, але і від педагогічної майстерності самого викладача, оволодіння ним методами і прийомами організації кооперативного навчання.

\section{IV Обговорення}

Результати наукового пошуку засвідчують той факт, що базові методи й прийоми організації кооперативного навчання були розроблені С. Каганом у 1980-1990-і роки. У науковому просторі вони відомі як структури С. Кагана:

- $\quad$ Numbered Heads Together («пронумеровані голови, які працюють разом»);

- $\quad$ Timed PairShare (тимчасова кооперація парами);

- Rally Robin (круглий стіл);

- Pairs Compare (порівняння парами);

- Kinesthetic Symbols (кінетичні символи) [7]. 
Названі структури, на переконання автора, не вимагають детального планування, спеціальної підготовки і досить прості у використанні. Одні з них регулюють взаємовідносини студентів, котрі працюють в парах, другі - більш прийнятні для організації командної роботи, треті - дозволяють організувати спільну роботу всіх членів академічної групи.

Утім, у національній вищій школі структури С. Кагана зазнали певних модифікацій, проте є широко вживаними. Одні з них є прямим запозиченням відомих зарубіжних практик, інші, - набули своєрідного забарвлення й грунтуються на національних традиціях організації кооперації в навчальному процесі. Розкриємо зміст і сформулюємо методичні рекомендації до деяких із них.

1. СТАД (STAD: Student Teams and Achievement). Розробниками цього методу $є$ Р. Славін і його колеги з університету Джона Хопкінса (1984р.). Для використання названого методу слід завчасно підготувати навчальний матеріал (підручники, посібники, робочі аркуші з переліком завдань) і контрольні запитання, що слугують алгоритмом для вивчення групою певної теми. Етапи реалізації СТАД: 1. Презентація викладачем теорії питання (концепції, процеси, навички). 2. Робота в групах (4-5 осіб) над заздалегідь підготовленим навчальним матеріалом. Завдання групи - допомагати кожному її члену засвоїти навчальний матеріал так, щоб добре написати контрольну роботу. 3. Контрольна робота, що має на меті перевірку якості засвоєного навчального матеріалу. Кожен член групи працює над її виконанням індивідуально. 4. Оцінювання індивідуальних навчальних досягнень. 5. Оцінка роботи групи (підрахунок балів, набраних всіма членами групи).

2. «Джигсо» (Jigsaw - «ажурна пилка»). Метод було розроблено професором Е. Аронсоном в 1978 р. Етапи проведення: 1. Студенти поділяються на групи (4-6 осіб) для виконання завдання, що поділене на декілька частин (логічні або змістові блоки). Кожен член малої групи вивчає конкретне питання (блок). 2. Студенти, котрі вивчали одне й теж питання в різних групах, зустрічаються й обмінюються набутою інформацією як експерти з цього питання. 3. Після спільного обговорення вони повертаються в малі групи і доповідають по черзі суть досліджуваного питання. Студенти зацікавлені в тому, щоб їхні товариші по команді добросовісно виконали своє завдання, оскільки від цього залежить загальна оцінка. 4. На підсумковому етапі викладач запрошує для відповіді на будь-яке питання за вивченою темою одного із членів команди (на вибір).

3. Навчання в командах досягнень. Цей метод кооперативного навчання приділяє особливу увагу «груповим цілям» і успіху всієї групи, досягнення якої можливе лише за умови самостійної роботи кожного члена малої групи в постійній взаємодії з іншими членами над виконанням поставленого завдання. Алгоритм реалізації цього метода такий: 1. Викладач подає оглядову лекцію за новим матеріалом, акцентуючи увагу на тих моментах, за якими команди будуть виконувати індивідуальні завдання. Лекція має бути достатньо ємною за змістом і мати практичну спрямованість. Рекомендовано використання наочності, моделювання й усних експериментів. 2. Студенти працюють над конспектом лекції, допомагаючи один одному засвоїти її зміст. Запитання викладачеві дозволяється ставити лише в тому разі, коли жоден із членів команди не дав на нього відповіді. 3. Виконання індивідуальної роботи кожним студентом. 4. Оцінювання самостійної роботи за прогресивно-порівняльним принципом: студент може поповнити копілку команди лише в тому разі, коли його оцінка за виконану роботу вища за середню його оцінку за попередні роботи. Команда, котра набрала за підсумками вивчення теми найбільшу кількість балів, вважається переможцем.

4. Метод навчального турніру. Проводиться після вивчення нового матеріалу. Під час турніру зустрічаються студенти із різних команд з однаковим рівнем навчальних досягнень. Порядок проведення: 1. студенти розподіляються на групи: перша - студенти з високим рівнем навчальних досягнень, друга - 3 середнім, третя - з низьким. 2. Кожна група отримує близько 30 пронумерованих карток з питаннями, які розташовані у вільному порядку. 3. Кожен член групи по черзі обирає картку і дає відповідь на питання, інші - дають оцінку відповіді за альтернативною шкалою (1 бал - вірно, 0 балів - невірно). В середньому на кожного студента припадає по 3 картки. Зважаючи на це, викладачу слід підготувати 90 карток трьох рівнів складності.) Після закінчення турніру члени груп повертаються в свої команди і сумують отримані бали. Перемагає команда, котра набрала найбільшу кількість балів.

5. Метод командної підтримки індивідуального навчання. Суть цього методу полягає в наданні малим групам можливості опановувати навчальну програму в індивідуальному темпі. Етапи проведення: 1. Студенти працюють у малих групах над індивідуальними завданнями, у процесі 
виконання яких можуть звертатися один до одного за порадою, допомогою чи консультацією. Студенти також можуть перевіряти роботи один одного, допомагати виправляти помилки. Викладач, у свою чергу, спостерігає за роботою малих груп, а також по черзі пояснює новий навчальний матеріал тим групам, які закінчили працювати над індивідуальним завданням. 2. Перевірка виконання індивідуальних завдань покладається на спеціально призначених викладачем студентів із різних груп. Вони отримують листивідповіді для оперативної перевірки індивідуальних робіт. 3. На завершення засвоєння курсу підводиться підсумок: сумарний навчальний результат за індивідуальними завданнями.

6. Метод кооперативного взаємонавчання. Полягає в постійній взаємодопомозі і взаємній підтримці студентів шляхом взаємоперевірок самостійних робіт, спільного виконання домашніх завдань, пояснення один одному вивченого матеріалу, спільної підготовки до заліків та іспитів. Цей метод доцільно застосовувати в роботі різних за фрормою навчальних груп: фрормальних (утворені за визначеними критеріями для розв'язання навчального завдання); неформальних (об'єднані за принципом симпатії, дружби або територіальним принципом); базових (ссрормовані для розв'язання довгострокових навчальних завдань протягом семестру, навчального року тощо).

7. Метод групового дослідження. Команди утворюються за неформальними ознаками, вивчають питання навчальної теми з метою підготовки групової доповіді і виступу перед групою. Питання за темою розподіляються між командами так, щоб охопити весь навчальний матеріал. Всередині команди кожен студент досліджує конкретне питання, збирає необхідний матеріал, надає його членам групи. На основі зібраних матеріалів формується загальна доповідь команди. За підготовлену доповідь кожна команда отримує групову оцінку.

8. Метод «Ко-оп Ко-оп» (Со-ор Со-ор). Метод було розроблено С. Каганом у 1986 р. Він спрямований на створення таких умов, за яких виникають і розвиваються природна допитливість, розумова обдарованість і емоційність тих, хто навчається. Названий метод близький до методу групового дослідження, але має одну відмінність: кожен член команди не просто готує матеріал за своєю темою, але й виступає з ним перед членами команди з міні-доповіддю. Після того, як сформульовано загальну доповідь команди, спікер спершу виступає з нею перед членами команди і лише потім (із урахуванням пропозицій членів команди і викладача) перед всією групою. Додатково студенти виконують ще й самостійну роботу за всією темою. Підсумкова оцінка групи включає як загальний бал за доповідь, так й індивідуальні бали за виконання самостійної роботи.

9. Пошуковий метод. Групи фрормуються для розв'язання будь-якого практично спрямованого навчального завдання або виконання прикладного проекту. Реалізація цього методу вимагає постановки завдань високого рівня проблемності і надання малим групам повної самостійності у пошуковій діяльності. Зважаючи на це, групи фрормуються за несрормальною ознакою. Ціль - провести міні-дослідження, яке вимагає творчого винахідницького підходу, щоб зібрати емпіричний матеріал, здійснити статистичну обробку результатів дослідження, сфрормулювати новизну отриманих результатів, оформити дослідження у вигляді доповіді і пройти процедуру «захисту» основних положень і результатів дослідження перед спеціальною експертною радою, до якої залучені викладачі, студенти, фахівці-роботодавці та ін.

10. Метод «Навчаємося разом». Перший варіант цього методу був розроблений в університеті штату Міннесота в 1987 р. Д. Джонсоном. Етапи проведення: 1. Академічна група поділяється на групи по три-п'ять осіб за рівнем навченості. 2. Кожна мала група отримує одне завдання, котре є складовою навчальної проблеми, над якою працює вся академічна група. У результаті спільної роботи малих груп досягається розв'язання загальної навчальної проблеми. Оцінюється робота малої групи залежно від досягнень кожного студента. 3 огляду на це, завдання в групах диференціюються за складністю і обсягом. Обов'язковою залишається вимога активної участі кожного члена малої групи у спільній роботі, але з урахуванням індивідуальних можливостей. За рекомендацією розробників цього методу слід особливу увагу приділяти комплектуванню малих груп (ураховувати індивідуальні і психологічні особливості кожного члена групи), а також розробленню завдань для кожної конкретної малої групи.

11. Триступеневе інтерв'ювання. Етапи проведення: 1. В групах із чотирьох осіб студенти утворюють пари і проводять у них інтерв'ю за темою програми. 2. Студенти змінюють ролі, інтерв'ю проводить колишній інтерв'юер. 3. По завершенні інтерв'ю студенти по черзі обмінюються інформацією, отриманою в ході інтерв'ю. 
12. Нумерація студентів. Етапи проведення: 1. Студенти розподіляються на малі групи, де кожному учаснику присвоюється порядковий номер. 2. Викладач ставить питання і просить, щоб «студенти разом подумали над відповіддю». 3. Викладач називає номер, і лише студенти під цим номером можуть підняти руку для відповіді.

13. Метод дискусії Л. Мітіної. Етапи проведення: 1. Студенти самі висуваю проблеми, які їх цікавлять. У процесі групової дискусії вони розташовують висунуті проблеми за ступенем важливості, значущості і виділяють найбільш «гостру» для вивчення в малих групах. 2. Викладач надає групі необхідний матеріал (базову інформацію за визначеною проблемою та рекомендовану літературу). 3. Обрана проблема стає предметом вивчення і обговорення в кожній малій групі. 4. Кожна група по черзі презентує свій матеріал (факти, приклади, обґрунтовану точку зору) усій навчальній групі. 5. Загальна дискусія: аналіз висловлених позицій, схвалення найбільш перспективних, доповнення різних точок зору, зміна ставлення до себе, до інших, до світу. 6. Після закінчення дискусії проводиться опитування, під час якого члени групи мають відповісти на декілька питань:1) Чи брали Ви активну участь у роботі групи? 2) Чи захопив Вас сам процес, якщо ні, то чому? 3) Чи відчували Ви на собі додатковий вплив інших членів групи? 4) Чи комфортно Вам було працювати в цій групі? Хотіли б Ви продовжити працювати в цьому складі й надалі? 5) Чи вважаєте Ви доцільним включення таких методів роботи в навчальний процес?

14. Метод проблемного семінарського заняття. Етапи проведення: 1. Постановка і осмислення проблеми. Викладач або один із студентів пропонує окремі погляди на визначену проблему. У процесі дискусії (не більше п'яти хвилин) студенти формулюють свої погляди на проблемну ситуацію, визначають «правила гри», визначають передбачуваний результат. 2. Генерування варіантів розв'язання проблеми. Студенти пропонують власні способи розв'язання проблеми, при цьому висловлені ідеї озвучуються без доказів. Приймаються до розгляду всі ідеї. їх фіксація здійснюється або викладачем, або одним із студентів. Кожному із студентів для виступу відводиться не більше 30 секунд. Максимальний поріг ідей - половині від кількості студентів у групі. 3. Пошук аргументів на підтримку кожного варіанта рішення проблеми. На цьому етапі студентська група поділяється на підгрупи (3-5 осіб). Відбувається жеребкування раніше висловлених варіантів. Далі команди мають за сім-десять хвилин надати якомога більше пропозицій і аргументів на захист ідеї, яка їм дісталася. Підкреслимо, що студенти мають працювати навіть з тими варіантами ідей, які їм не подобаються, але дісталися в процесі жеребкування. 4. Відбір найбільш аргументованих варіантів рішень. Для аргументації своєї ідеї від кожної підгрупи делегується один представник, який має представити роботу підгрупи перед аудиторією за одну-дві хвилини. За підсумками виступів відбирається половина найбільш прийнятних аргументів, над якими студенти продовжують роботу. 5. Критика відібраних варіантів рішень. Студентська група знову розбивається на підгрупи (3-5 осіб), серед яких проводиться жеребкування варіантів ідей, які залишилися. Завдання підгрупи за сім-десять хвилин висловити якомога більшу кількість критичних зауважень на адресу ідеї, що дісталася в ході жеребкування. Чим більше недоліків, «білих плям» виявить підгрупа у варіанті розв'язання проблеми, тим легше буде знайти правильне рішення проблеми. 6. Відбір рішень, найбільш стійких до критики. Цей етап аналогічний четвертому. У результаті залишається тільки половина ідей, критика яких буде найбільш переконливою. 7. Аналіз способів реалізації відібраних рішень. Знову відбувається поділ студентів на групи, здійснюється жеребкування способів рішення загальної проблеми. 8. Обговорення цих способів. У ході третього туру обговорення прийнятними є як позитивні, так і негативні виступи. Доцільно, щоб у підсумку залишилося декілька переможців. Відповідно, основне завдання цього етапу - показати студентам, що не існує одного правильного способу розв'язання проблеми. 9. Підведення підсумків.

Зазначимо, що названі методи адаптовані до вітчизняної освітньої практики вищої школи. Їх можна комбінувати і використовувати у поєднанні з традиційними методами навчання під час лекцій, семінарських, практичних і лабораторних занять. Це дозволить підвищити ефективність освітнього процесу і якість навчання,поліпшити взаємовідносини між студентами, створити міцне підґрунтя для формування в них самостійності, критичного мислення, оволодіння навичками пізнавальної діяльності, а також особистісного й соціального розвитку. 


\section{IV Висновки}

Отже, проведене дослідження дає підстави для висновку, що в умовах інформаційного суспільства культура навчання й уміння навчатися стають більш затребуваними, ніж власне самі програми навчання. Відповіддю на виклики сьогодення, зокрема в умовах організації освітнього процесу в закладах вищої освіти, є застосування технології кооперативного навчання, в основу якої покладено особистісно орієнтований підхід, розвиток пізнавальних умінь і навичок самостійно конструювати наявні знання і здобувати нові. Теоретико-методологічні засади технології кооперативного навчання складають теорія соціальної взаємозалежності, теорія навчання, спрямована на когнітивний розвиток особистості, i біхевіористська теорія навчання. Не дивлячись на певні розбіжності щодо внутрішніх і зовнішніх спонук в успішній реалізації кооперативного навчання, названі теорії відстоюють позицію про те, що кооперативне навчання забезпечує кращий результат, ніж навчання конкурентне й індивідуальне. Воно має потужні важелі для розвитку мотивації тих, хто навчається; формування в них самостійності, критичного мислення, комунікативних здібностей, оволодіння навичками пізнавальної діяльності й соціальними вміннями.

Не зважаючи на те, що методичний інструментарій технології кооперативного навчання було розроблено зарубіжними науковцями (Д. Джонсон, Р. Джонсон, Е. Джонсон-Холубек, С. Каган та ін.) вітчизняна освітня практика, зокрема вищої школи, здійснює активний пошук методів і прийомів кооперативного навчання, адаптуючи їх до національних особливостей і традицій. Найбільш ефективними з-поміж них уважаємо: метод навчання в командах досягнень; метод командної підтримки індивідуального навчання; метод групового дослідження; пошуковий метод; метод дискусії Л. Мітіної; метод проблемного семінарського заняття.

Стаття розширює результати досліджень вітчизняних науковців [16; 19; 22; 24; 25; 26 ], пропонуючи узагальнені методичні рекомендації до організації кооперативного навчання у вищій школі. Перспективним видається статистичний аналіз результатів педагогічного експерименту щодо впровадження технології кооперативного навчання у процесі фрахової підготовки майбутніх фармацевтів.

\section{Бібліографрічні посилання}

[1] Aronson E., \& Patnoe S. Cooperation in the Classroom: The Jigsaw Method. New York: Addison Wesley Longman, 1997.

[2] Aronson E., Blaney N., Stephan C., Sikes J., \& Snapp M. The Jigsaw Classroom. Beverly Hills, CA Sage, 1978.

[3] Borsch F. Kooperatives Lehren und Lernen im schulischen Unterricht. Stuttgart, 2010. 63 p.

[4] Circles of learning. Cooperation in the classroom / [Johnson David W., Johnson Roger T., Holubec Edythe Johnson, Roy P]. Alexandria, Va. : Association for Supervision and Curriculum Development, 1984. $89 \mathrm{p}$.

[5] Cooperative Learning Returns To College : What Evidence Is There That It Works? / [Johnson David W., Johnson Roger T., Smith Karl A.] / Change. 1998. July / August. P. 27-35.

[6] Johnson D. W. Social Interdependence Theory and Cooperative Learning : The Teacher's Role / D. W. Johnson and R. T. Johnson; [Gillies Robyn M., Ashman Adrian F., Terwel Jan] / The Teacher's Role in Implementing Cooperative Learning in the Classroom. NY : Springer Science+Business Media, LLC, 2008. Chapter 1. P. 9-37.

[7] Kagan S., Kagan M. Kagan cooperative learning. CA : Kagan Publishing, 2000. 479 p.

[8] Kagan S. Kagan structures and learning together - what is the difference? [Електронний pecypc] Kagan online magazine. 2001. Режим доступу до статті : http://www.kaganonline.com/free_articles/dr_spencer_kagan/ASK13.php.

[9] Levin K.A. Dynamic Theory of Personality. New York : McGraw-Hill, 1935. 376 p.

[10] MacGregor, J. "Collaborative Learning: Shared Inquiry as a Process of Reform." In M. Svinicki, (Ed.) The Changing Face of College Teaching. New Directions for Teaching and Learning, no. 42, San Francisco: Jossey-Bass, 1990.

[11] Renegar S. L. All of us know more than each of us : cooperative learning in higher education / Active Learning Strategies for the Higher Education. Szeged : JATEPress, 1997. P. 47-57.

[12] Slavin R. E. An Introduction to Cooperative Learning Research / Learning to cooperate, cooperating to learn. N. Y.; L. : Plenum Press, 1985. C. 5-12

[13] Weidner M. Kooperatives Lernen im Unterricht. Kallmeyer : Klett, 2006. $192 \mathrm{p}$.

[14] Волкова Н.П., Тарнапольський О. Б. Моделювання професійної діяльності у викладанні навчальних дисциплін у вишах: монографія. Дніпропетровськ: Дніпропетровський ун-т імені Альфреда Нобеля, 2013. 228 с.

[15] Выготский Л. С. Психология развития человека. М. : Изд-во Смысл; Эксмо, 2005. 1136 с.

[16] Гагіна Н. В. Кооперативне навчання у вищій школі. Вісник Житомирського державного університету імені Івана Франка. 2012. Вип. 64. С. 98-102.

[17] Джонсон Д., Джонсон Р., Джонсон-Холубек Э. Методы обучения. Обучение в сотрудничестве. СПб., 2001. 245 с.

[18] Дьюи Дж. Демократия и образование / пер. с англ. М. : Педагогика-пресс, 2000. 
[19] Комар О. Засвоюємо інтерактивні технології навчання. Психолого-педагогічні проблеми сільської школи. 2008. Вип. 26. С. 81-88.

[20] Кутбидинова Р.А. Методы активного социально-психологического обучения: учеб.-метод. пособие. Южно-Сахалинск : из-во СахГу, 2014. 136 c.

[21] Пиаже Ж. Избранные психологические труды. М. : Междунар. Пед. Акад., 1994. 580 с.

[22] Пометун О. І. Енциклопедія інтерактивного навчання. К., 2007. 144 с.

[23] [23] Пометун О.І., Пироженко Л.В. Сучасний урок. Інтерактивні технології навчання: Наук.-метод. посібник. К.: А.С.К., 2004. 192c.

[24] Пускаева Т.Д. Современные модели кооперативного обучения: методики США. Химия в школе. 1993. №3. С. $43-45$.

[25] Селевко Г.К. Энциклопедия образовательных технологий : В 2 т. Т. 1. М.: НИИ школьных технологий, 2006. 816 с.

[26] Стрельніков В. Ю., Брітченко І. Г. Сучасні технології навчання у вищій школі: модульний посібник для слухачів авторських курсів підвищення кваліфікації викладачів МІПК ПУЕТ. Полтава : ПУЕТ, 2013. 309 с.

\section{References}

[1] Aronson, E. and Patnoe, S. (1997), Cooperation in the Classroom: The Jigsaw Method, New York, Addison Wesley Longman, $160 \mathrm{p}$.

[2] Aronson, E., Blaney, N., Stephan, C., Sikes, J. and Snapp, M. (1978), The Jigsaw Classroom, Beverly Hills, CA Sage.

[3] Borsch, F. (2010), Kooperatives Lehren und Lernen im schulischen Unterricht, Stuttgart, 63 p. [in Germain]

[4] Johnson, David W., Johnson, Roger T., Holubec, Edythe Johnson and Roy, P. (1984), Circles of learning. Cooperation in the classroom, Alexandria, Va. : Association for Supervision and Curriculum Development, $89 \mathrm{p}$.

[5] Johnson, David W., Johnson, Roger T. and Smith, Karl A. (1998), Cooperative Learning Returns To College : What Evidence Is There That It Works?, Change, July / August, pp. 27-35.

[6] Johnson, D. W. and Johnson, R.T. (2008), Social Interdependence Theory and Cooperative Learning : The Teacher's Role, in Gillies, Robyn M., Ashman, Adrian, F. and Terwel, Jan, The Teacher's Role in Implementing Cooperative Learning in the Classroom, NY, Springer Science+Business Media, LLC, Chapter 1, pp. 9-37.

[7] Kagan, S. and Kagan, M. (2000), Kagan cooperative learning, CA, Kagan Publishing, 479 p.

[8] Kagan, S. (2001), Kagan structures and learning together - what is the difference? Kagan online magazine, available at:http://www.kaganonline.com/free_articles/dr_spencer_kagan/ASK13.php. (accessed April 06, 2019)

[9] Levin, K.A. (1935), Dynamic Theory of Personality, New York : McGraw-Hill, 376 p.

[10] MacGregor, J. (1990), Collaborative Learning: Shared Inquiry as a Process of Reform, in M. Svinicki, (Ed.) The Changing Face of College Teaching. New Directions for Teaching and Learning, no. 42, San Francisco: Jossey-Bass, pp. 19-30.

[11] Renegar, S.L. (1997), All of us know more than each of us : cooperative learning in higher education, Active Learning Strategies for the Higher Education, Szeged : JATEPress, pp. 47-57.

[12] Slavin, R.E. (1985), An Introduction to Cooperative Learning Research, Learning to cooperate, cooperating to learn, N.Y.; L. : Plenum Press, pp. 5-12.

[13] Weidner, M. (2006), Kooperatives Lernen im Unterricht, Kallmeyer : Klett, 192 p. [in Germain]

[14] Volkova, N.P. and Tarnapolskyy, O.B. (2013), Modelyuvannya profesiynoyi diyal'nosti u vykladanni navchalnykh dystsyplin u vyshakh: monohrafiya, Dnipropetrovsk Univ named A. Nobel, Dnipropetrovsk, 228 p. [in Ukrainian]

[15] Vygotsky, L.S. (2005), Psykholohyya razvytyya cheloveka, Moscow, Publishing House Smysl, Eksmo, 1136 p. [in Russian]

[16] Hahina, N.V. (2012), Kooperatyvne navchannya u vyshchiy shkoli, Bulletin of Zhytomyr State Univ. after Ivan Franko, Iss. 64, pp. 98-102. [in Ukrainian]

[17] Johnson, D., Johnson, R. and Johnson-Holubeck, E. (2001), Metody obuchenyya. Obuchenye v sotrudnychestve, St. Petersburg, 2001, 245 p. [in Russian]

[18] Dewey, J. (2000), Demokratyya y obrazovanye, Translation from English, Moscow, Pedahohyka-press, 2000, 384 p. [in Russian]

[19] Komar, O. (2008), Zasvoyuyemo interaktyvni tekhnolohiyi navchannya, Psychological and pedagogical problems of rural school, Iss. 26, pp. 81-88. [in Ukrainian]

[20] Kutbydynova, R.A. (2014), Metody aktyvnoho sotsyal'no-psykholohycheskoho obuchenyya: ucheb.-metod. posobye. Yuzhno-Sakhalynsk : Publishing House SakhHu, 136 p. [in Russian]

[21] Pyazhe, J. (1994), Yzbrannye psykholohycheskye trudy, Moscow, International Ped. Acad., 580 p. [in Russian]

[22] Pometun, O.I. (2007), Entsyklopediya interaktyvnoho navchannya, Kyiv, 144 p. [in Ukrainian]

[23] Pometun, O.I. and Pyrozhenko, L.V. (2004), Suchasnyy urok. Interaktyvni tekhnolohiyi navchannya: Nauk.-metod. Posibnyk, Kyiv, A.S.K., 192 p. [in Ukrainian]

[24] Puskaeva, T.D. (1993), Sovremennye modely kooperatyvnoho obuchenyya: metodyky SShA, Chemistry at school, №3, pp. 43-45. [in Russian]

[25] Selevko, H.K. (2006), Éntsyklopedyya obrazovatel'nykh tekhnolohyy: In 2 vol., Vol. 1. Scientific Research Institute of School Technologies, Moscow, 816 p. [in Russian]

[26] Strel'nikov, V.U. and Britchenko, I.H. (2013), Suchasni tekhnolohiyi navchannya u vyshchiy shkoli: modul'nyy posibnyk dlya slukhachiv avtors'kykh kursiv pidvyshchennya kvalifikatsiyi vykladachiv MIPK PUET, PUET, Poltava, 309 p. [in Ukrainian] 


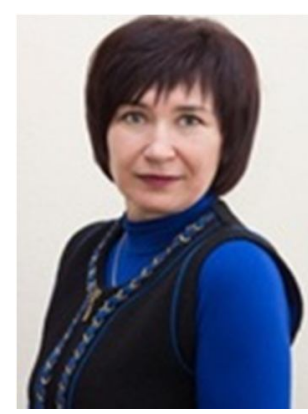

Зеленська Людмила Дмитрівна,

доктор педагогічних наук, профресор

Харківський національний педагогічний університет імені Г. С. Сковороди,

вул. Алчевських, 29, м. Харків, Україна, 61002.

Тел. +38 0963520308. E-mail: zelenskaya_ludmila@ukr.net

\section{Zelenska Liudmyla Dmytrivna.}

Doctor of Pedagogical Sciences, Full Professor, Professor of the Department of General Pedagogy and

Pedagogy of Higher School H.S. Skovoroda Kharkiv National Pedagogical University,

29 Alchevskyh Street, Kharkiv, Ukraine, 61002.

Tel. +38 0963520308. E-mail: zelenskaya_ludmila@ukr.net

ORCID: orcid.org/0000-0002-3324-5173

Researcher ID: H-1334-2019

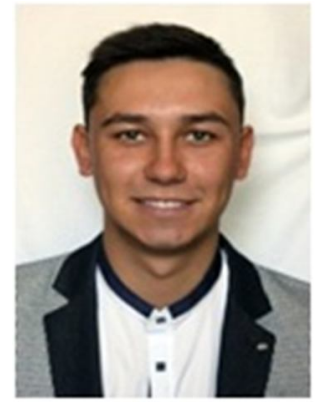

\section{Зеленський Богдан Романович,}

аспірант кафедри початкової, дошкільної та професійної освіти,

Харківський національний педагогічний університет імені Г.С. Сковороди,

вул. Алчевських, 29, м. Харків, Україна, 61002.

Тел. +38 0507868765. E-mail: zelja18061993@gmail.com

\section{Zelenskyi Bohdan Romanovych.}

Post-graduate student of the Department of General Pedagogy and Pedagogy of

Higher School H.S. Skovoroda Kharkiv National Pedagogical University

29 Alchevskyh Street, Kharkiv, Ukraine, 61002.

Tel. +38 0507868765. E-mail: zelja18061993@gmail.com

ORCID: https://orcid.org/0000-0003-4223-7834

\section{Citation (APA):}

Zelenska, L., Zelenskyi, B. (2019). Theoretical and methodological bases of organization of cooperative education in higher educational institutions. Engineering and Educational Technologies, 7 (2), 19-29. doi: https://doi.org/10.30929/23079770.2019.07.02.02

\section{Цитування (ДСТУ 8302:2015):}

Зеленська Л. Д., Зеленський Б. Р. Теоретичні і методичні засади організації кооперативного навчання у закладах вищої освіти / Інженерні та освітні технології. 2019. Т. 7. № 2. С. 19-29. doi: https://doi.org/10.30929/2307-9770.2019.07.02.02

Обсяг статmі: $\quad$ сторінок-11 ; умовних друк. аркушів - 1,593. 